University of Nebraska - Lincoln

DigitalCommons@University of Nebraska - Lincoln

$6-18-2020$

\title{
Climate change impacts the subsurface transport of atrazine and estrone originating from agricultural production activities
}

Renys Enrique Barrios

Simin Akbariyeh

Chuyang Liu

Khalid Muzamil Gani

Margarita T. Kovalchuk

See next page for additional authors

Follow this and additional works at: https://digitalcommons.unl.edu/watercenterpubs

Part of the Environmental Indicators and Impact Assessment Commons, Fresh Water Studies Commons, Hydraulic Engineering Commons, Hydrology Commons, Sustainability Commons, and the Water Resource Management Commons

This Article is brought to you for free and open access by the Water Center, The at DigitalCommons@University of Nebraska - Lincoln. It has been accepted for inclusion in Faculty Publications from The Water Center by an authorized administrator of DigitalCommons@University of Nebraska - Lincoln. 


\section{Authors}

Renys Enrique Barrios, Simin Akbariyeh, Chuyang Liu, Khalid Muzamil Gani, Margarita T. Kovalchuk, Xu Li, Yusong Li, Daniel D. Snow, Zhenghong Tang, John Gates, and Shannon L. Bartelt-Hunt 


\title{
Climate change impacts the subsurface transport of atrazine and estrone originating from agricultural production activities
}

\author{
Renys E. Barrios, ${ }^{1}$ Simin Akbariyeh, ${ }^{2}$ Chuyang Liu, ${ }^{1}$ \\ Khalid Muzamil Gani, ${ }^{3}$ Margarita T. Kovalchuk, ${ }^{1} \mathrm{Xu} \mathrm{Li,}{ }^{1}$ \\ Yusong $\mathrm{Li}^{1}{ }^{1}$ Daniel Snow, ${ }^{4}$ Zhenghong Tang, ${ }^{5}$ \\ John Gates, ${ }^{6}$ and Shannon L. Bartelt-Hunt ${ }^{1}$
}

1 Department of Civil and Environmental Engineering, University of NebraskaLincoln, Lincoln, NE, 68588, United States

2 Department of Civil Engineering, Construction Management \& Environmental Engineering, Northern Arizona University, Flagstaff, AZ, 86011, United States

3 Institute for Water and Wastewater Technology, Durban University of Technology, PO Box 1334, Durban, 4000, South Africa

4 Water Sciences Laboratory, University of Nebraska-Lincoln, Lincoln, NE, 68503, United States

5 College of Architecture, Community and Regional Planning Program, University of Nebraska-Lincoln, Lincoln, NE, 68588, United States 6 The Climate Corporation, San Francisco, CA, 94103, United States

Corresponding author — S. L. Bartelt-Hunt, email sbartelt@unl.edu

Renys E. Barrios and Simin Akbariyeh are co-equal first authors.

Published in Environmental Pollution 265 (2020) 115024

doi:10.1016/j.envpol.2020.115024

Copyright (c) 2020 Elsevier Ltd. Used by permission.

Submitted 26 February 2020; revised 10 June 2020; accepted 10 June 2020; published 18 June 2020.

This paper was recommended for acceptance by Charles Wong. 


\begin{abstract}
Climate change will impact soil properties such as soil moisture, organic carbon and temperature and changes in these properties will influence the sorption, biodegradation and leaching of trace organic contaminants to groundwater. In this study, we conducted a modeling case study to evaluate atrazine and estrone transport in the subsurface under current and future climate conditions at a field site in central Nebraska. According to the modeling results, in the future, enhanced evapotranspiration and increased average air temperature may cause drier soil conditions, which consequently reduces the biodegradation of atrazine and estrone in the water phase. On the other hand, greater transpiration rates lead to greater root solute uptake which may decrease the concentration of atrazine and estrone in the soil profile. Another consequence of future climate is that the infiltration and leaching rates for both atrazine and estrone may be lower under future climate scenarios. Reduced infiltration of trace organic compounds may indicate that lower trace organic concentrations in groundwater may occur under future climate scenarios.
\end{abstract}

Keywords: Climate change, Subsurface transport, Trace organics, Groundwater, Agricultural production

\title{
1. Introduction
}

There is a strong dependence between global water sustainability and agriculture, as agricultural production accounts for nearly $70 \%$ of freshwater usage worldwide (The USGS Water Science School). In areas including the US Corn Belt, grasslands are being increasingly converted to soybean and corn production (Wright and Wimberly, 2013) and the US is producing record high amounts of red meat and poultry (USDA ERS 2016). This increased agricultural intensification has coincided with increased chemical inputs necessary for crop and animal production such as pesticides, antimicrobials, and steroid hormones. Although the fate and transport of nutrients derived from agricultural systems has attracted much attention, potential impacts due to climate and climate-induced land use changes on the fate, transport, and environmental health impacts of these trace level constituents remain largely unexplored (Bloomfield et al., 2006).

Atrazine and estrone are two trace organic compounds which have been related to health and environmental concerns. Atrazine has been a commonly used herbicide for decades and has been identified in groundwater (Kolpin et al., 2002; Spalding et al., 2003a) and in the source water used for drinking water by over 28 million US residents (Benotti et al., 2009). Exposure to atrazine reduces the maturation 
process in frog oocytes and induces death in the first stages of embryogenesis (Ji et al., 2016). Exposure to steroid hormones such as estrone have been demonstrated to lead to a number of documented health impacts including abnormal expression of reproductive characteristics in aquatic organisms (Rose et al., 2013); abnormal development of the gonads causing intersex fish (Tetreault et al., 2011; Vajda et al., 2011); and reduction of fish biomass (Hallgren et al., 2014). There is a critical need to understand the occurrence and behavior of these trace organic compounds in groundwater under scenarios of changing geochemical and hydrological regimes introduced by climate change.

Currently, only a limited number of studies have explored the influence of climate change on organic contaminant transport in the environment. Prior modeling studies have demonstrated that some expected environmental changes, such as temperature increase, modification of precipitation patterns, and sea level rise, will lead to noticeable variations in the concentration and mobility of these contaminants in surface water (Delcour et al., 2015; Lamon et al., 2009; Valle et al., 2007). There is less information available regarding direct climate change impacts on contaminant fate in groundwater. Previous studies have proposed that climate change may affect trace organic fate in the subsurface through changes in seasonality and intensity of rainfall events and increases in temperature (Bloomfield et al., 2006; Steffens et al., 2015), and decreases in soil moisture and soil organic carbon (Falloon et al., 2006).

In this study, we conducted a modeling study of a corn production area in Central Nebraska to demonstrate the impacts of climate change on trace organic contaminant fate in the subsurface. We specifically evaluated the impact of current and predicted future climate conditions on the transport of the herbicide atrazine and estrone, a naturally produced steroid hormone present in cattle manure.

\section{Materials and methods}

\subsection{Study area}

The study area was described previously (Akbariyeh et al., 2018). Briefly, the area was part of the Management System Evaluation Area 

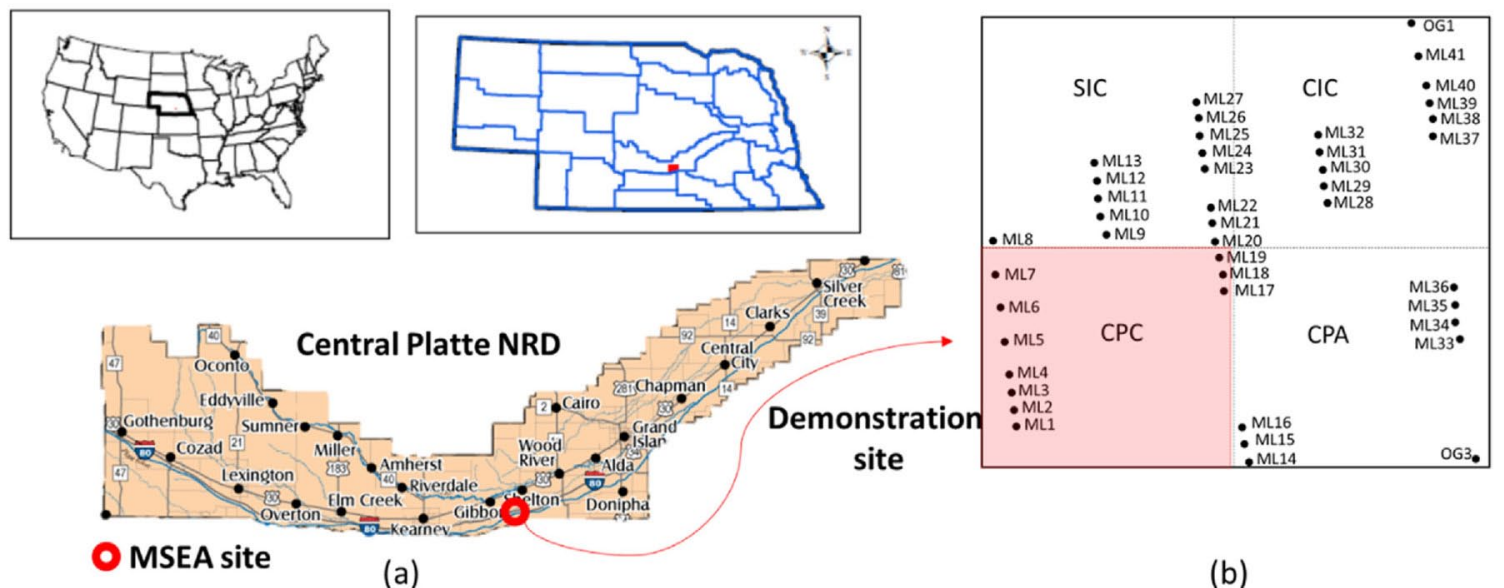

(b)

Fig. 1. Central Platte Nebraska's Natural Resources Districts (CPNRD), (a) the location of the MSEA site on NRD map, (b) demonstration site with four management fields and 41 multilevel samplers.

(MSEA) site in Nebraska, a $2.27 \mathrm{~km}^{2}$ site studied in the 1990s to evaluate the impact of irrigation strategies on groundwater quality. Fig.1a shows the location of the MSEA site which belongs to the Central Platte Natural Resources District (CPNRD) (Schepers et al., 1995; Spalding et al., 2001). At this location, the annual mean precipitation and temperature are $623 \mathrm{~mm}$ and $10{ }^{\circ} \mathrm{C}$, respectively (McGuire and Kilpatrick, 1998). During 1993-1996, nitrate-nitrogen (N) concentration and groundwater level were measured at the site using 41 multilevel samplers (Fig. 1 b), and the $\mathrm{N}$ fertilizer application rates and yearly irrigation water were also monitored. We simulated atrazine and estrone fate under a center-pivot irrigated corn plot (CPC) at the MSEA site (Fig. 1b).

The vadose zone of shallow aquifer in this area is mainly welldrained sand and gravel. Although this aquifer is the major source of water for both irrigation and drinking, the groundwater was highly contaminated with atrazine as a result of intensive agricultural activities. Groundwater atrazine concentration within the contaminated area ranged $0.1-4 \mu \mathrm{g} / \mathrm{L}$ (University of Nebraska- Lincoln, 2000).

\subsection{Climate data}

We downscaled the climate data at a resolution of $24 \times 24 \mathrm{~km}^{2}$ using the Weather Research and Forecasting (WRF) model (Skamarock et 
al., 2008). For more information about WRF model, see our previous work (Akbariyeh et al., 2019). In this study, we controlled and validated the WRF model using a set of data from 2006 to 2010 and predicted future climate from 2056 to 2060. Because WRF model has 119 nodes in both the vertical and horizontal directions, we used the coordinates of nodes (latitude and longitude) to extract the points within the MSEA site. MSEA site future climatic parameters (i.e. precipitation and air temperature) were estimated as the average values of 4 nodes mostly adjacent to the site.

\subsection{Modeling approach}

\subsubsection{Model setup}

We simulated water flow and solute transport including atrazine and estrone in a 2-m soil profile using Hydrus-1D. Simulations were performed under both past (1993-1996) and future climate conditions (2057-2060) to compare the direct impact of climate change on the soil moisture content and the atrazine and estrone concentration distribution. The past simulation period was selected based on the availability of historical field measurement during this time period. The future simulation period was selected based on WRF model which predicted future climate from 2056 to 2060 . The past and future simulation length was kept same for the purpose of comparison. The most abundant soil type in the MSEA site, sandy soil, was defined for all simulations.

\subsubsection{Water flow governing equations}

Water flow was simulated through solving Richard's equation:

$$
\frac{\partial \theta}{\partial t}=\frac{\partial}{\partial z}\left[K(h)\left(\frac{\partial h}{\partial z}+1\right)\right]-S
$$

where, $\theta$ is the volumetric water content $\left[\mathrm{L}^{3} / \mathrm{L}^{3}\right], \mathrm{h}$ is the pressure head $[L], t$ is time $[\mathrm{T}], z$ is the spatial coordinate $[\mathrm{L}], K(h)$ is the unsaturated hydraulic conductivity [L/T] (i.e., product of saturated hydraulic conductivity $\mathrm{K}_{\mathrm{s}}[\mathrm{L} / \mathrm{T}]$ and relative hydraulic conductivity, $\mathrm{K}_{r^{\prime}}$ and $S$ is a sink 
term $[1 / T]$ accounting for water uptake by roots. The relationship between unsaturated hydraulic conductivity and water saturation was described by (Mualem, 1976; van Genuchten, 1980):

$$
\begin{aligned}
& K(h)=K_{s} S_{e}^{\prime}\left[1-\left(1-S_{e}^{1 / m}\right)^{m}\right]^{2} \\
& S_{e}=\frac{\theta(h)-\theta_{r}}{\theta_{s}-\theta_{r}}=\left[1+|\alpha h|^{n}\right]^{-m}
\end{aligned}
$$

where, $S_{e}$ is effective water saturation $[-], \theta_{s}$ and $\theta_{r}$ are the saturated and residual water content $[-]$, respectively, $\alpha[1 / L], m$, and $n[-]$ are empirical parameters related to soil type where $m=1-1 / n$, and $l$ is tortuosity coefficient [-] (assumed to be 0.5 (Mualem, 1976)).

Water stress response function was used to describe the water uptake by plant roots (i.e., S, in equation (1)) (Feddes et al., 1978):

$$
S(h)=\alpha(h) S_{p}, \quad S_{p}=\frac{1}{L_{z}} T_{p}
$$

where, $\alpha(h)$ is a soil water pressure head function $(0 \leq \alpha \leq 1)[-]$, and $S_{p}$ is rate of potential water uptake $[1 / T], T_{p}$ is the rate of potential transpiration $[L / T], L_{z}$ is the root zone depth [L] (assumed to be $1 \mathrm{~m}$ ("Soil and Health Library," 2016)). When water content was near saturation or pressure head was below the wilting point (Feddes et al., 1978), we considered that water uptake was zero.

\subsubsection{Solute transport governing equations}

In the simulation, atrazine and estrone were applied at the top of the soil profile. The governing equation used to simulate the solute transport in the variably saturated porous media assuming first order reaction was (Simunek et al., 2012):

$$
\frac{\partial \theta c}{\partial t}+\rho \frac{\partial s}{\partial t}=\frac{\partial}{\partial z}\left(\theta D_{j} \frac{\partial c_{k}}{\partial x_{j}}\right)-\frac{\partial q c}{\partial z}-\mu_{w} \theta c-\mu_{s} \rho s-S c_{r}
$$

where, $c$ and $s$ are the solute concentrations in liquid $\left[M / L^{3}\right]$ and solid phase $[\mathrm{M} / \mathrm{M}]$, respectively, $\rho$ is the soil bulk density $\left[\mathrm{M} / \mathrm{L}^{3}\right], D_{j}$ is the effective dispersion coefficient tensor $\left[\mathrm{L}^{2} / \mathrm{T}\right]$ for the liquid phase 
Table 1. Soil properties.

\begin{tabular}{lr} 
Parameter & Soil \\
\hline Texture class & Sand \\
$\boldsymbol{f}_{\text {oc }}(\%)$ & 0.1 \\
Bulk density $\left(\mathrm{kg} \mathrm{m}^{-3}\right)^{\text {a }}$ & 1600 \\
Residual water content, $\boldsymbol{\theta}_{\boldsymbol{r}}$ & 0.045 \\
Saturated water content, $\boldsymbol{\theta}_{\boldsymbol{s}}$ & 0.43 \\
Empirical parameter, $\boldsymbol{\alpha}\left(\mathrm{m}^{-1}\right)$ & 14.5 \\
Empirical parameter, $\boldsymbol{n}$ & 2.68 \\
Saturated hydraulic conductivity, $\boldsymbol{K}_{\boldsymbol{s}}\left(\mathrm{m} \mathrm{d}^{-1}\right)$ & 7.128 \\
Tortuosity coefficient, $\boldsymbol{l}$ & 0.5 \\
Longitudinal dispersivity, $\boldsymbol{D}_{\boldsymbol{L}}(\mathrm{m})$ & 1.16 \\
\hline
\end{tabular}

a. http://www.agriinfo.in/?page=topic\&superid=4\&topicid=271

(calculated using a scale-dependent empirical method (Neuman, 1990) (Table 1)), $q$ is the density of volumetric flux $[\mathrm{L} / \mathrm{T}], \mu_{w}$ and $\mu_{s}$ are first-order decay rate constants in liquid and solid phases $[1 / T]$, respectively, $S$ is the sink term $\left[\mathrm{L}^{3} / \mathrm{L}^{3} / \mathrm{T}\right]$ in the equation of water flow (eq. (1)), and $c_{r}$ is the concentration of the sink term $\left[\mathrm{M} / \mathrm{L}^{3}\right]$. To simulate the sorption of atrazine to solid phase, we used a linear sorption isotherm model. $K_{d}$ is the distribution coefficient $\left[\mathrm{L}^{3} / \mathrm{M}\right]$ which was calculated based on $K_{o c}$ of 2.204 [log $1 / \mathrm{kg}$ ] (i.e., partitioning coefficient of soil organic carbon-water ("GSI ENVIRONMENTAL INC.," 2013)) and $f_{\text {oc }}$ of $0.1 \%$ (i.e., mass fraction of soil organic carbon content (Table 1 )). $f_{\text {oc }}$ value was measured in lab from soil samples collected from the field. Freundlich adsorption isotherm was defined for estrone with $\beta$ equal to 0.51 according to experimental results.

To simulate the root uptake of solute, root water uptake $S$ was multiplied by the dissolved solute concentration $\left(c_{r}\right)$, when $c_{r}$ was lower than the maximum root solute concentration $c_{\max } c_{\max }$ was considered as $9 \mathrm{~kg} / \mathrm{m}^{3}$ for atrazine (Roeth and Lavy, 1971) and $0.002 \mathrm{~kg} / \mathrm{m}^{3}$ for estrone (Card et al., 2012).

\subsubsection{Initial and boundary conditions}

The model was simulated from April 1, 1993 to March 20, 1996 for the past climatic condition (base model) and from April 1, 2057 to March 20, 2060 for the future climatic condition. The initial pressure head along the soil profile was determined by assuming a hydrostatic 
equilibrium in the unsaturated zone based on the initial groundwater level. For the past climatic condition, the initial groundwater level was gathered from the groundwater level monitoring data in the field on April 1, 1993. The initial groundwater level for the future climatic condition was based on the predicted groundwater level on April 1, 2057 as described in (Akbariyeh et al., 2019). That work indicated that groundwater level will gradually decrease at an average rate of $20 \mathrm{~cm} / \mathrm{y}$ from 2027 to 2060. The initial atrazine concentration in the subsurface was considered as $0.8 \mathrm{mg} / \mathrm{m}^{3}$ based on the reported value in Spalding et al. (2003a) and the initial estrone concentration was assumed as zero, for both past and future conditions.

An atmospheric boundary condition with surface runoff was applied at the soil surface. When precipitation rate was higher than infiltration rate of water (i.e., saturation conditions in the soil), water ponding was not allowed at soil surface. During 1993-1996, daily precipitation and potential evapotranspiration data (ET for reference crop, alfalfa) were collected from Shelton weather station at the High Plane Regional Climate Center (HPRCC, https://hprcc.unl.edu/stationtool.php). For the past model, the amount of total yearly irrigation was applied at a constant daily rate from late June to end of September (i.e., throughout the irrigation season) (Table 2) (Spalding et al., 2001). We assumed that corn will still be cultivated in that area because of lack of data regarding future land use. Future irrigation application rates (Table 2) were decided following an approach typically used in the past, where irrigation rate was considered as proportional to the precipitation amount in the growing season.

Table 2 Modeling parameters.

\begin{tabular}{|c|c|c|c|c|c|c|c|c|}
\hline \multirow[b]{3}{*}{ Root Dist. (m) } & \multirow[t]{2}{*}{. } & \multirow{2}{*}{\multicolumn{3}{|c|}{ Solute Transport }} & \multicolumn{4}{|c|}{ Field Data } \\
\hline & & & & & \multicolumn{4}{|c|}{ Irrigation $[\mathrm{mm}]^{\mathrm{c}}$} \\
\hline & & & Atrazine ${ }^{a}$ & Estrone $^{b}$ & Past & & Future & \\
\hline Max. root d & 1 & $\mathrm{~K}_{\mathrm{d}}\left(\mathrm{m}^{3} \mathrm{mg}^{-1}\right)$ & $1.6 \times 10^{-10}$ & $1.6 \times 10^{-8}$ & 1993 & 79 & 2057 & 95 \\
\hline \multirow[t]{2}{*}{ Max. intensity d } & 0.3 & $k\left(d^{-1}\right)$ & 0.0770 & 0.0228 & 1994 & 107 & 2058 & 85 \\
\hline & & $C_{0}\left(m^{3} \mathrm{mg}^{-1}\right)$ & 0.8 & 0 & 1995 & 307 & 2059 & 100 \\
\hline
\end{tabular}

a. Atrazine properties were retrieved from literature (Spalding et al., 2003b).

b. Estrone properties were examined in lab experiments.

c. Irrigation application rates were retrieved from Spalding et al. (2001). 
Under future climate data, daily precipitation values were adopted from the predicted climate data in WRF model. Hargreaves equation was used to calculate potential evapotranspiration $\left(\mathrm{ET}_{\mathrm{p}}\right)$ (Hargreaves, 1994):

$$
E T_{p}=0.0023 R_{a}\left(T_{m}+17.8\right) T R^{1 / 2}
$$

where $R_{a}$ is extraterrestrial radiation in the same unit as $E T_{p}\left[\mathrm{~J} \mathrm{~m}^{-2} \mathrm{~s}^{-1}\right.$ or $\left.\mathrm{mm} \mathrm{d}^{-1}\right], T_{m}$ is the mean air temperature $\left[{ }^{\circ} \mathrm{C}\right]$, and $T R$ is the range of temperature between the maximum and minimum air temperature $\left[{ }^{\circ} \mathrm{C}\right]$. Hargreaves equation estimates $\mathrm{ET}_{\mathrm{p}}$ using only temperature and latitude information, which was widely recognized as the proper method to calculate $\mathrm{ET}_{\mathrm{p}}$ when lacking data to use in Penman-Monteith equation (Gavilán et al., 2006). Bear's law was applied to differentiate the potential evaporation and transpiration (Šejna and Šimůnek, 2007), by using the leaf area index (LAI) of the US-Ne2 site, which is another research field belonging to the University of Nebraska with soybean rotation and irrigated maize ("AmeriFlux Site and Data Exploration System," 2016).

At the bottom of the soil profile, free drainage boundary condition was defined, while groundwater table was assumed to be at deeper than $2 \mathrm{~m}$ beneath the ground surface. The third type (i.e., Cauchy type) concentration boundary condition was specified for solute transport at the surface boundary to prescribe fertilizer application. Based on the historical records of herbicides loading to shallow groundwater beneath the MSEA site (Spalding et al., 2003b), $1.68 \mathrm{~kg} / \mathrm{ha}$ atrazine was applied on top between April 29th to May 20th of each year. For estrone a continuous concentration with half-year cycles of 0.75 and $1.5 \mathrm{mg} / \mathrm{m}^{3}$ was applied each year at the top boundary (Arnon et al., 2008). At the bottom of the profile, zero concentration flux boundary condition was used.

\subsubsection{Parameter sensitivity analysis}

Parameter sensitivity analysis was performed to evaluate the impacts of evapotranspiration, irrigation rate, atrazine and estrone application rates, and sorption and reaction coefficients on the transport and accumulation of atrazine and estrone. 
Evapotranspiration is one of the significant atmospheric parameters which was predicted to rise in future and soil will be drying out, consequently. To further investigate the impacts of higher evapotranspiration rates, we evaluate the impacts of $\mathrm{ET}_{\mathrm{p}}$ on the transport and accumulation of atrazine and estrone by increasing the $\mathrm{ET}_{\mathrm{p}}$ values to be 1.5- and 2-times higher than the predicted value in future climate scenario.

In the base future model, the irrigation application rate was defined with respect to the ratio of precipitation and irrigation during the growing season, in a similar approach as the applied in the past. With the enhanced evapotranspiration rate and drier soil condition in future, there is a high possibility that irrigation will be increased correspondingly. Furthermore, irrigation applications could be increased in future to improve agricultural productivity. Therefore, we simulated the future model with 2- and 3-times higher irrigation as alternative over-irrigation scenarios.

In addition to irrigation application rates, the concentration application rates will most likely change in future to either accommodate with continued population growth and increased food demand, or with water sustainability management plans to improve water quality. To reflect each of these scenarios, we considered scenarios 33\% less and $33 \%$ more concentration applications at the soil surface for both atrazine and estrone.

We also evaluated the effects of uncertainty in contaminant properties in terms of $\mu_{w}$ (first order decay rate) and $k_{d}$ (adsorption isotherm coefficient). We simulated scenarios with $50 \%$ of defined $\mu_{w}$ and $k_{d}$ values as well as 1.5 times higher $\mu_{w}$ and $k_{d}$ values for both atrazine and estrone.

\section{Results and discussion}

\subsection{Comparison of future and past climate conditions}

Fig. 2 compares the amount of monthly precipitation and $\mathrm{ET}_{\mathrm{p}}$ between the past and future. Total precipitation during 1993-1996 was 2040 $\mathrm{mm}$, which was lower compared to the total precipitation of $2205 \mathrm{~mm}$ during 2057-2060. On average, $84 \%$ of total precipitation in the past 

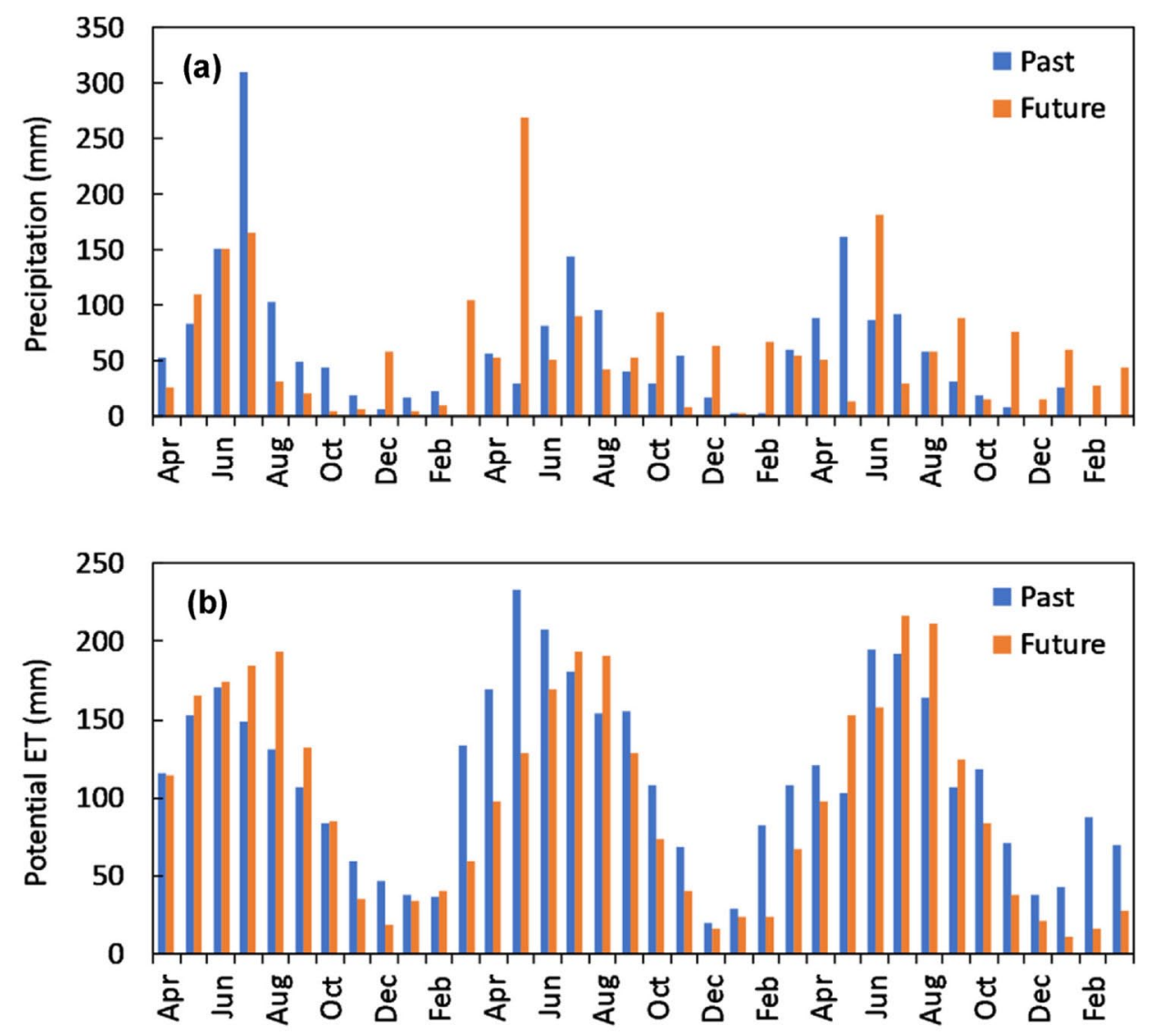

Fig. 2. Monthly (a) precipitation and (b) ETp from 4/1/1993 to 3/20/1996 (past) and $4 / 1 / 2057$ to $3 / 20 / 2060$ (future).

occurred during growing seasons (Apr. 21st to Dec. 1st) while $77 \%$ of total future precipitation was predicted to happen during growing seasons. Total $\mathrm{ET}_{\mathrm{p}}$ was $4045 \mathrm{~mm}$ during the simulated period in the past which was slightly greater than the calculated $\mathrm{ET}_{\mathrm{p}}(3548 \mathrm{~mm})$ in the future.

Average air temperature was about $10{ }^{\circ} \mathrm{C}$ with a minimum of -29 ${ }^{\circ} \mathrm{C}$ and a maximum of $40{ }^{\circ} \mathrm{C}$ during $1993-1996$. Future mean air temperature increases to about $15^{\circ} \mathrm{C}$ with a minimum and a maximum of $-22{ }^{\circ} \mathrm{C}$ and $38{ }^{\circ} \mathrm{C}$, respectively. Higher mean air temperature may enhance the volatilization flux of pesticides (Ma et al., 2004; Ma and Cao, 2010). For instance, when the mean air temperature increased $1^{\circ} \mathrm{C}$, the mean volatilization flux of organochlorine pesticides from soils increased 8\% (Komprda et al., 2013). In a future climate scenario, 
higher temperatures may enhance the volatilization of atrazine from agricultural soils.

Higher mean air temperature may increase soil temperature which influences the sorption of atrazine and hormones in the subsurface. As the temperature increases, atrazine and testosterone experience less attachment to soil particles (Qi and Zhang, 2016; Urena-Amate et al., 2005). For instance, Freundlich sorption coefficients for testosterone in clay soil decreased from $196[(\mathrm{ng} / \mathrm{kg})(\mathrm{ng} / \mathrm{L})-\mathrm{n}]$ at $4{ }^{\circ} \mathrm{C}$ to $94[(\mathrm{ng} / \mathrm{kg})$ (ng/L)-n] at $35^{\circ} \mathrm{C}$ (Qi and Zhang, 2016). Similarly, when temperature increased from $10{ }^{\circ} \mathrm{C}$ to $40^{\circ} \mathrm{C}$, atrazine showed a decreased affinity for the active sites in kerolite (Urena-Amate et al., 2005). Because climate change will promote higher soil temperatures, the sorption of atrazine and hormones in a future climate scenario may be decreased.

Higher temperatures may accelerate microbial degradation of pesticides at the surface soil and subsoil (Caracciolo et al., 2001; Kookana et al., 2010). For instance, the biodegradation rate of atrazine in a sandy-loam soil collected at the surface $(0-20 \mathrm{~cm})$ increased from $0.015 \mathrm{~d}^{-1}$ to $0.057 \mathrm{~d}^{-1}$ when temperature increased from $5^{\circ} \mathrm{C}$ to $35^{\circ} \mathrm{C}$, respectively (Dong and Sun, 2016). Similar behavior was observed for estrogen hormones. The biodegradation rate of $17 \beta$-estradiol in a loam soil increased from $0.21 \mathrm{~d}^{-1}$ to $0.52 \mathrm{~d}^{-1}$ when temperature increased from $4{ }^{\circ} \mathrm{C}$ to $30^{\circ} \mathrm{C}$, respectively (Colucci et al., 2001). Taken together, in a future climate scenario, increases of mean air temperature and subsequently, soil temperature, may decrease the sorption of atrazine and estrone, but enhance the volatilization and biodegradation of these trace organic compounds.

\subsection{Water flux and soil moisture content}

In Fig. 3a, the actual evapotranspiration $\left(\mathrm{ET}_{\mathrm{a}}\right)$ rate under the future climate scenario is compared to the past. Overall, the total actual $\mathrm{ET}_{\mathrm{a}}$ during 2057-2060 (from Hydrus simulation results), was 1500 mm, which was higher than total $\mathrm{ET}_{\mathrm{a}}$ of $1400 \mathrm{~mm}$ during 1993-1996.

Enhanced $\mathrm{ET}_{\mathrm{a}}$ can cause drier soil conditions within the root zone, which consequently influences the biodegradation of atrazine and its metabolites deethylatrazine (DEA) and deisopropylatrazine (DIA), by impacting their residence time and half-lives (Dong and Sun, 2016; Sonon and Schwab, 2004). For example, the biodegradation products 

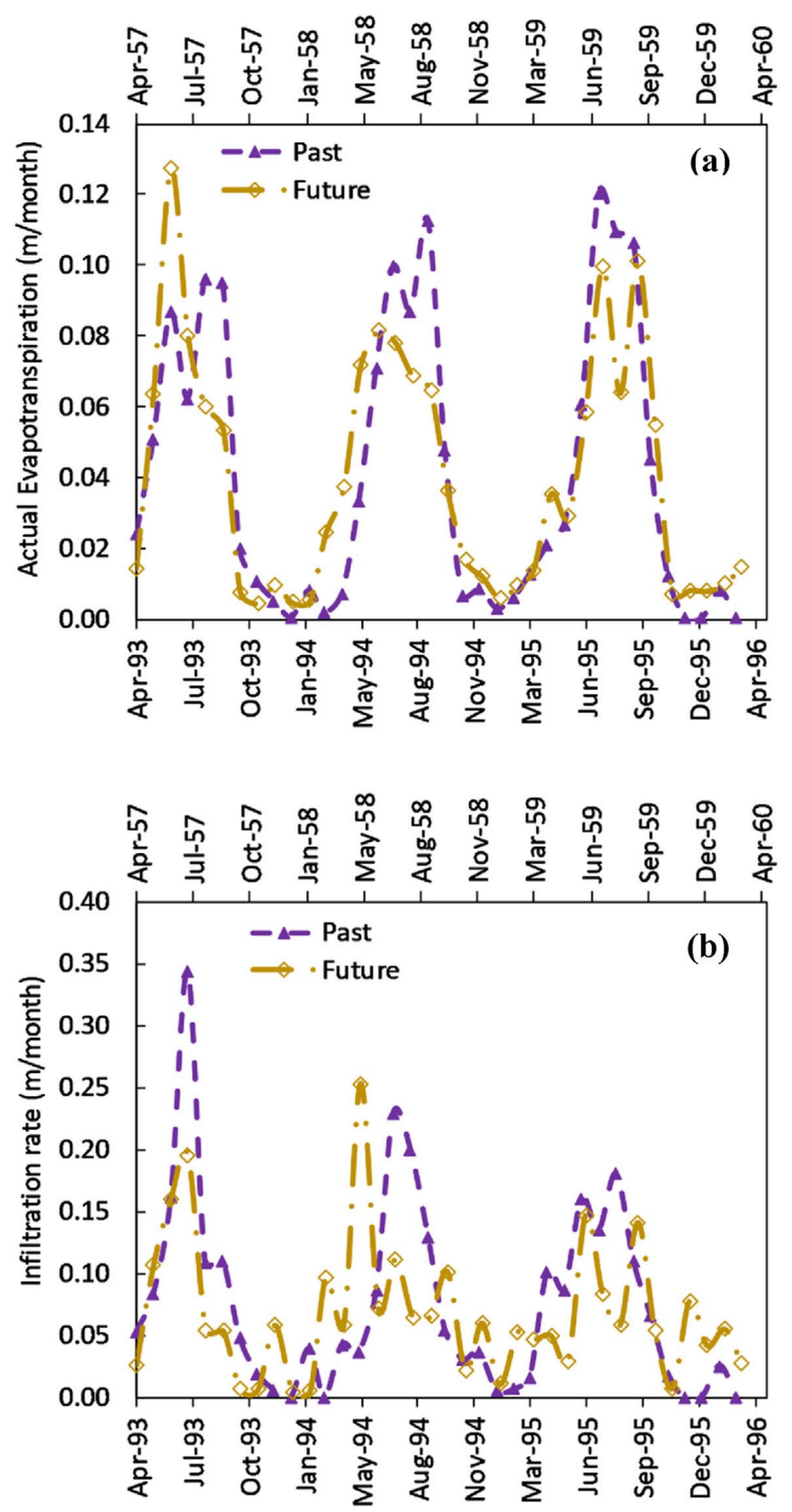

Fig. 3. (a) $E T_{a}$ rates, (b) monthly infiltration rates. 
of atrazine, DEA and DIA, were formed in a soil column with 40\% soil moisture content, but not in a soil column with $~ 70 \%$ soil moisture content due to decreased residence time (Sonon and Schwab, 2004). On the contrary, atrazine half-life increased from $8 \mathrm{~d}$ to $16 \mathrm{~d}$ when the soil moisture decreased from $25 \%$ to $5 \%$, respectively (Barrios et al., 2019). In a future climate scenario, drier soils may affect biodegradation of pesticides by increasing residence time, limiting microbial activities, and chemical availability.

On the other hand, greater transpiration rate means greater root solute uptake which may decrease the concentration of atrazine and estrone in the soil profile. Uptake of pesticides has been reported for switchgrass (Albright and Coats, 2013; Lin et al., 2008; Moeder et al., 2017), poplar trees (Chang et al., 2005), and rice seedlings (Su and Zhu, 2006). In the case of hormones, uptake has been reported for wetland macrophytes, poplar trees, leafy vegetables, and maize (Bircher et al., 2015; Card et al., 2013, 2012; Shargil et al., 2016).

\subsection{Concentration of atrazine and estrone}

The amount of atrazine and estrone in the soil profile depended on root solute uptake, solute leaching rate, biodegradation rate, and surface loading rate. The temperature sensitivity of biodegradation rate was not considered in the model simulation. For comparison purposes, equal masses of contaminants were applied at the ground surface for past and future scenarios.

\subsubsection{Atrazine}

As shown in Fig. 4a, temporal changes of total atrazine mass (both dissolved and sorbed mass) in the soil profile demonstrated higher amounts under the past climatic conditions. According to Fig. 4a, the mass of atrazine in the soil increased during its application period (between April 29th to May 20th of each year) and decreased during the other period of the year. In general, the total mass of atrazine was lower in the profile under the future climate scenario. Fig. 4b shows the mean concentration of atrazine in the dissolved phase only, which also followed a similar trend to the total mass of atrazine in the profile. 

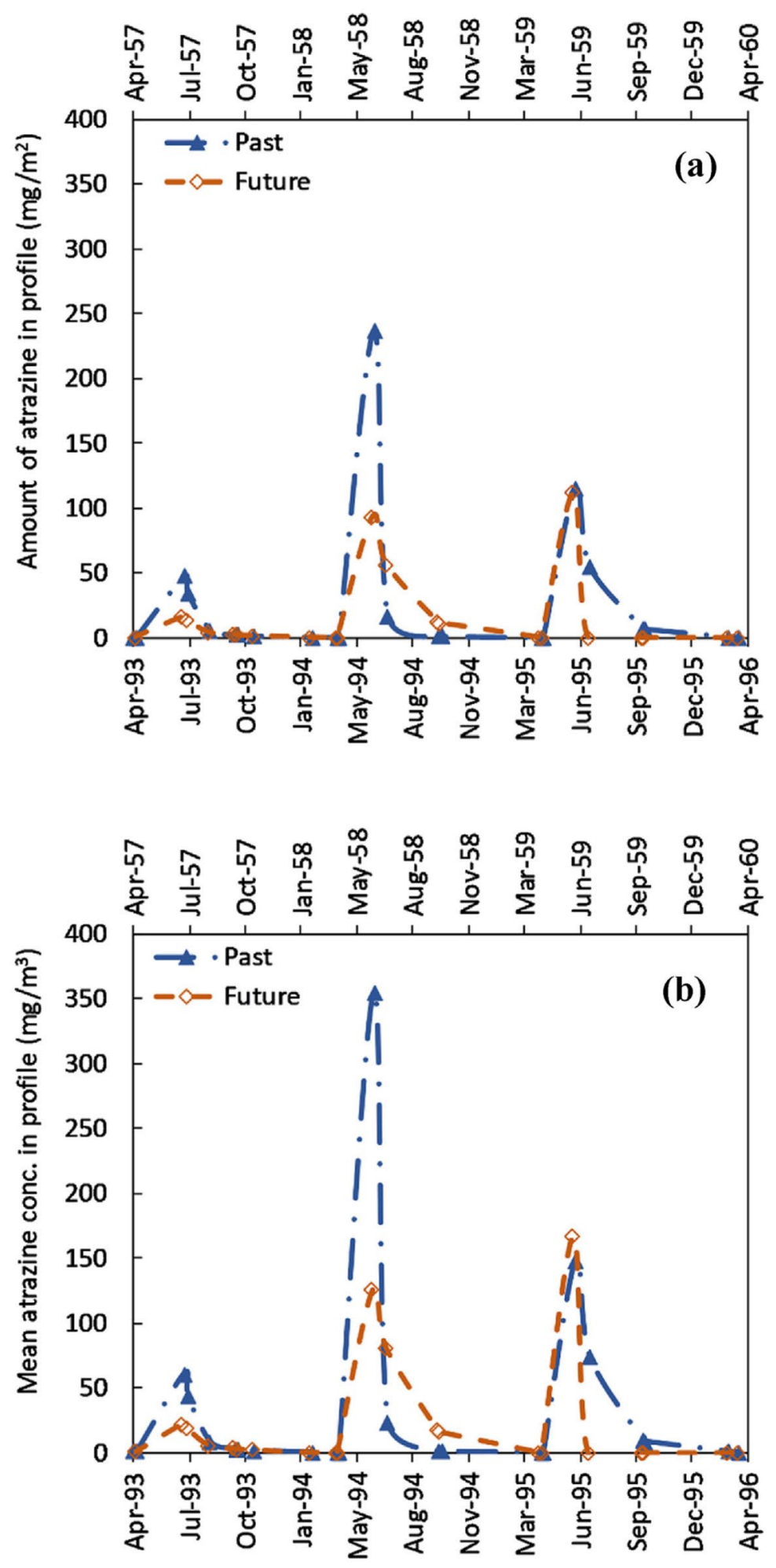

Fig. 4. Atrazine, (a) total mass in the entire soil profile in equilibrium phases, including sorbed, (b) mean concentration in the soil profile (dissolved phase). 
According to Fig. 3b, a similar pattern can be seen in the infiltration rates between the past and future models. The average infiltration rate under the past climate data was about $0.08 \mathrm{~m} / \mathrm{d}$, which was higher compared to $0.07 \mathrm{~m} / \mathrm{d}$ infiltration rate under the future climate scenario. This was consistent with the average unsaturated hydraulic conductivity of the profile (the average value in the entire soil profile and in all time), which was found almost two times higher in the past model $(0.0014 \mathrm{~m} / \mathrm{d})$ than in the future model $(0.0008 \mathrm{~m} / \mathrm{d})$. The difference in infiltration resulted in different rates of mass flux. Total atrazine flux out from the bottom of the profile was about $6 \mathrm{mg} / \mathrm{m}^{2}$ higher under the past climate condition than the future climate condition, which showed that atrazine leaching rate decreased in the future climatic condition. Similarly, previous studies have reported that the interaction between changes in precipitation (i.e., higher infiltration rates) and temperature (i.e., enhanced degradation) due to climate change conditions resulted in a decrease in pesticide concentrations in the leachate (Barrios et al., 2019; Steffens et al., 2015).

\subsubsection{Estrone}

As shown in Fig. 5a the amount of estrone in the profile (both dissolved and sorbed mass) was increasing during the simulation period under both past and future climate conditions. Estrone was applied continuously throughout the simulation period. Due to the root solute uptake, the concentration was dropping during the growing season but the average amount of estrone have steadily risen. However, the amount of estrone was generally lower under future climate scenario, which was due to increased $\mathrm{ET}_{\mathrm{a}}$ rate and decreased infiltration rate. According to the estrone concentration profile on selected days (i.e. 184th, 366th, and 914th after the start of the simulation) (Fig. 5c), estrone only reached about $0.5 \mathrm{~m}$ from the ground surface, less than $10 \mathrm{~cm}$ deeper in the past than in the future, due to higher infiltration rates in the past. The much lower leaching rate of estrone than atrazine was due to higher sorption onto soil surfaces; hormones are highly sorbed (Casey et al., 2005, 2003; Lee et al., 2003). As demonstrated in Fig. 5b, the mean concentration of estrone in the dissolved phase (Fig. 5b)was only about $2 \%$ of the total mass (Fig. $5 a$ ) in the profile. Because estrone never reached the bottom of boundary during the simulation period, water and mass flux at the bottom boundary did not have as much influence on estrone as on atrazine. 

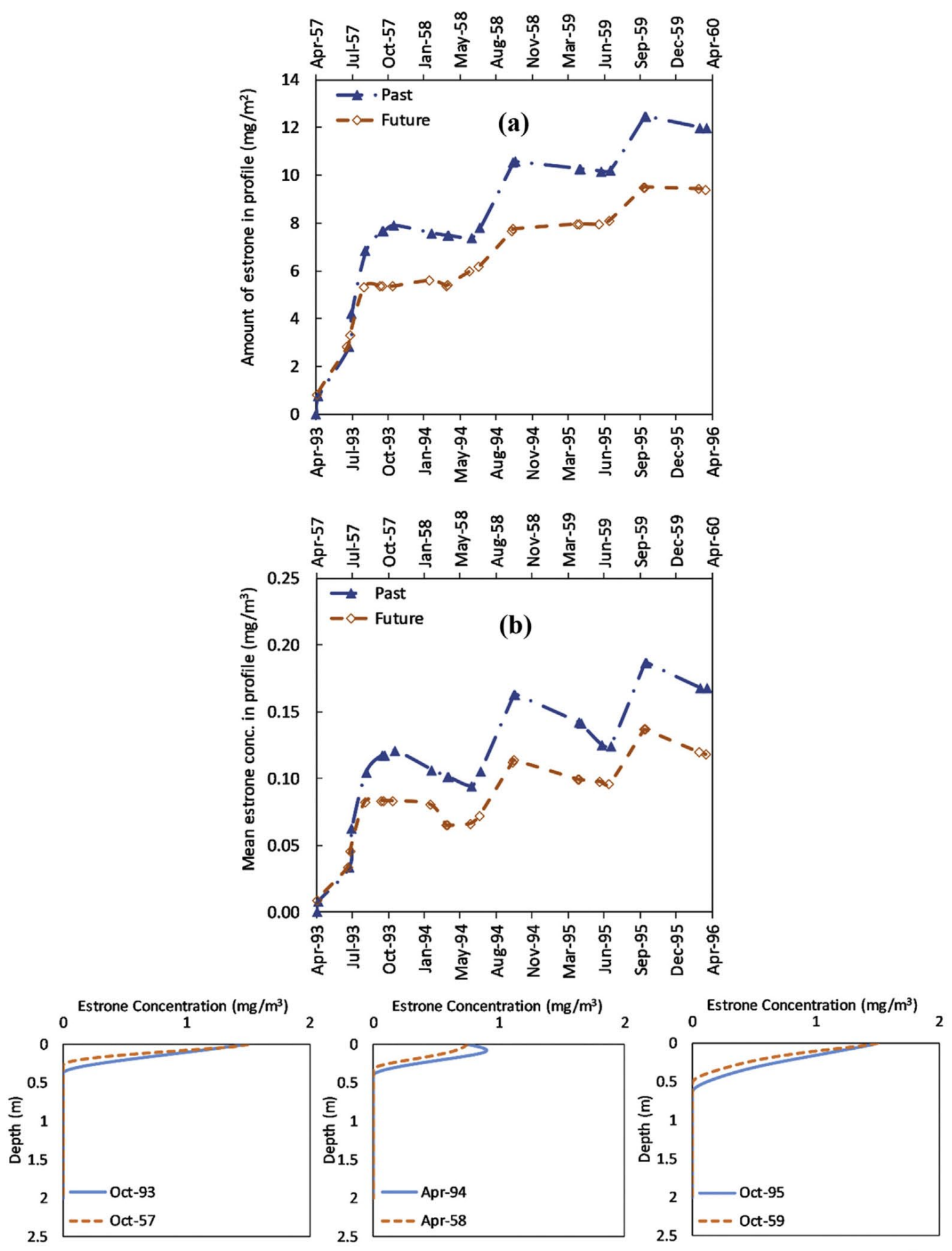

(c)

Fig. 5. Estrone (a) total mass in the soil profile in equilibrium phases, including sorbed, (b) mean concentration in the soil profile (dissolved phase), and (c) concentration profile on days 184th, 366th, and 914th after simulation started. 
Overall, the leaching rate of estrone in the profile was found considerably lower than atrazine. The leaching rate was higher under past climate condition compared to the future climate for both atrazine and estrone.

\subsection{Uncertainties due to climatic conditions, application rates, and properties of contaminants}

Increased irrigation rate did not influence the atrazine concentration considerably in the profile (Fig. 6a); however, estrone concentration raised by $8 \%$ and $20 \%$ with 2 - and 3-times higher irrigation, respectively (Fig. 6b). For atrazine, the concentration is applied prior to the growing season (between April 29th to May 20th of each year). Therefore, the total mass of atrazine was independent of the irrigation rates and mainly depended on the precipitation amounts. For estrone, the concentration was continuously applied at the soil surface. Accordingly, the greater infiltration rate caused by doubling and tripling the irrigation rates during the growing season increased the total mass of estrone in the field.

The average mass of atrazine and estrone in the soil profile increased by $34 \%$ and $24 \%$, respectively, as a result of $33 \%$ higher concentration application. However, $33 \%$ less application rate reduced the atrazine concentration to three-times and estrogen concentration to two-times lesser values (Fig. 6a and b). The impact of irrigation on the accumulation of atrazine and estrone could be of great importance to future water management strategies.

Total mass of atrazine and estrone were found to decrease in the soil profile when increasing the $\mathrm{ET}_{\mathrm{p}^{\prime}}$ which is mainly due to reduced surface solute flux entering the system (Fig. $6 a$ and b). Surface flux of estrone dropped by $10 \%$ and $16 \%$ for 1.5 - and 2-times higher $\mathrm{ET}_{\mathrm{p}^{\prime}}$ respectively. On the contrary, mass of atrazine increased in the soil during the atrazine application period in 2059 (Fig. 6a). Looking at the modeling results, it was found that the precipitation amount in this period is the lowest compared with other years. With increasing the $\mathrm{ET}_{\mathrm{p}^{\prime}}$ actual evaporation raised during the whole simulation period, however, the actual transpiration rate was found to be decreasing due to very dried soil condition during the atrazine application period in 

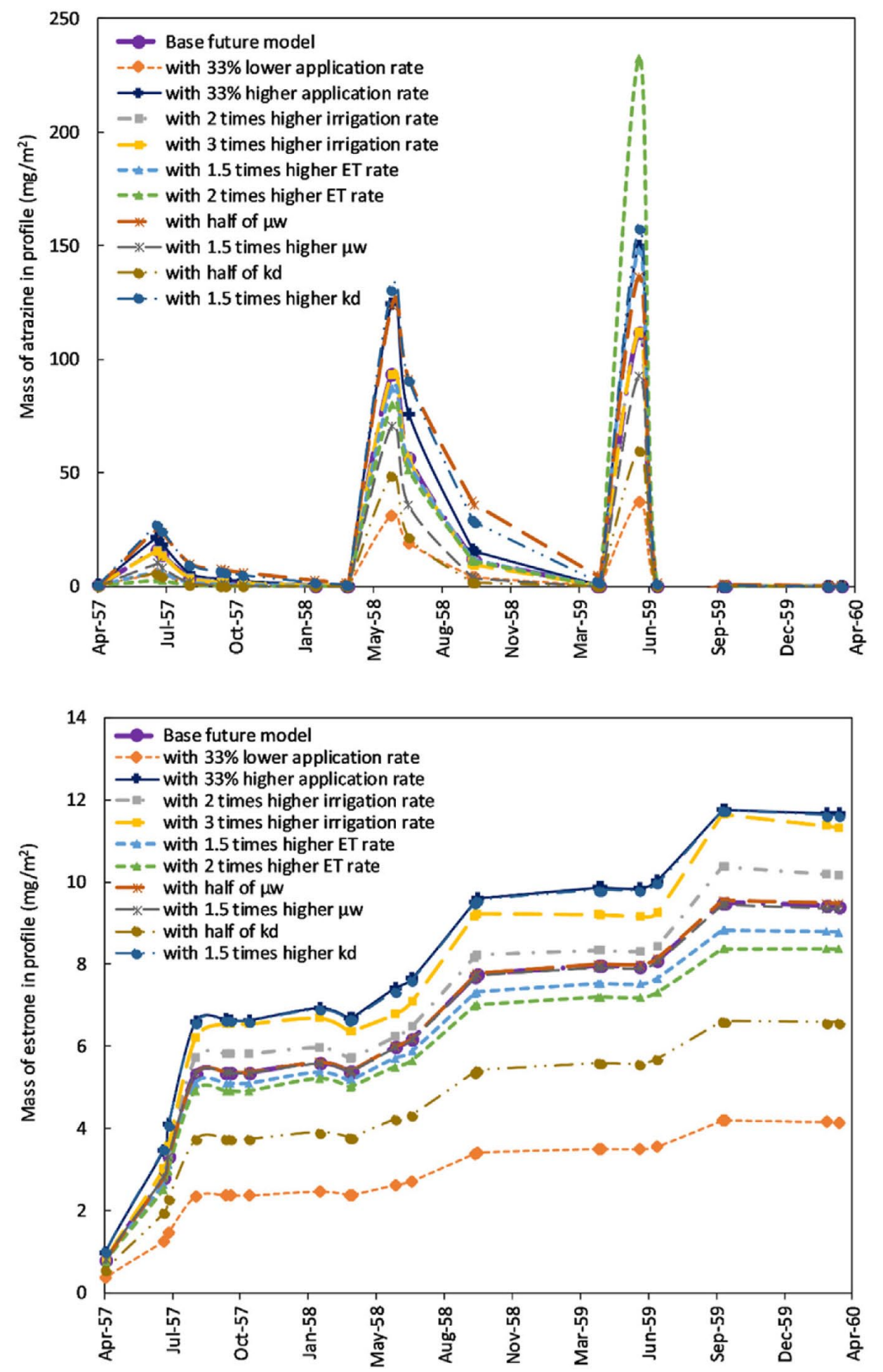

Fig. 6. Amount of (a) atrazine and (b) estrone in the soil profile including dissolved and sorbed phases under different scenarios. mw represents the first-order decay rate constant for dissolved phase and $\mathrm{kd}$ is adsorption isotherm coefficient. 
2059. The combined effects of low precipitation and high evaporation rate resulted in a low root atrazine uptake which caused greater mass of atrazine retained within the soil.

Half of decay rate resulted in $63 \%$ higher atrazine mass in the soil while 1.5 -times higher decay rate lowered the mass by $43 \%$. Changing the decay rate for estrone had the minimum effect on its mass, since estrone has a very small reaction rate constant. Fig. 6 represents the amounts of atrazine and estrone in the soil profile including dissolved and sorbed phases. Therefore, half of the adsorption coefficient decreased the mass of atrazine and estrone by $55 \%$ and $30 \%$, respectively. While, $60 \%$ more atrazine and $23 \%$ higher estrone was found in the soil with 1.5 -times higher $k_{d}$ values.

\section{Conclusions}

In the future, enhanced evapotranspiration and increased average air temperature may cause drier soil conditions, which consequently reduces the biodegradation of atrazine and estrone in the water phase. On the other hand, greater transpiration rate means greater root solute uptake which may decrease the concentration of atrazine and estrone in the soil profile. Another consequence of future climate is that the infiltration and leaching rates for both atrazine and estrone may be higher under past climate conditions compared to the future climate. Reduced infiltration of trace organic compounds may indicate that lower trace organic concentrations in groundwater may occur under future climate scenarios. When uncertainty of climatic conditions is considered, the impact of irrigation on the accumulation of atrazine and estrone could be of great importance to future water management strategies.

Competing interests The authors declare that they have no known competing financial interests or personal relationships that could have appeared to influence the work reported in this paper.

Acknowledgments Authors thank the Robert B. Daugherty Water for Food Institute and USDA NIFA for providing support for this project (Grant 2014- 67003-22072). The authors gratefully acknowledge the contributions of Eric Thompson, David Rosenbaum and Junpyo Park. R. Barrios and S. Akbariyeh provided equal contribution to the manuscript and should be considered co-first authors. 


\section{CRediT authorship contribution statement}

Renys E. Barrios: Investigation, Writing - original draft.

Simin Akbariyeh: Methodology, Investigation, Writing - original draft.

Chuyang Liu: Methodology, Investigation, Writing - original draft.

Khalid Muzamil Gani: Writing - original draft, Investigation.

Margarita T. Kovalchuk: Methodology, Investigation, Writing - original draft.

Xu Li: Conceptualization, Writing - original draft, Supervision.

Yusong Li: Conceptualization, Methodology, Writing - original draft, Supervision.

Daniel Snow: Conceptualization, Writing - original draft.

Zhenghong Tang: Methodology, Writing - original draft.

John Gates: Conceptualization.

Shannon L. Bartelt-Hunt: Conceptualization, Supervision, Writing - original draft.

Supplementary data Supplementary data to this article will be made available upon request.

\section{References}

Akbariyeh, S., Bartelt-Hunt, S., Snow, D., Li, X., Tang, Z., Li, Y., 2018. Threedimensional modeling of nitrate- $\mathrm{N}$ transport in vadose zone: roles of soil heterogeneity and groundwater flux. J. Contam. Hydrol. 211, 15-25. https://doi. org/10.1016/j.jconhyd.2018.02.005

Akbariyeh, S., Gomez Pena, C.A., Wang, T., Mohebbi, A., Bartelt-Hunt, S., Zhang, J., Li, Y., 2019. Prediction of nitrate accumulation and leaching beneath groundwater irrigated corn fields in the Upper Platte basin under a future climate scenario. Sci. Total Environ. 685, 514-526. https://doi.org/10.1016/j. scitotenv.2019.05.417

Albright, V.C., Coats, J.R., 2013. Disposition of atrazine metabolites following uptake and degradation of atrazine in switchgrass. Int. J. Phytoremediation 16, 62-72. https://doi.org/10.1080/15226514.2012.759528

AmeriFlux Site and Data Exploration System, 2016. https://ameriflux.lbl.gov/

Arnon, S., Dahan, O., Elhanany, S., Cohen, K., Pankratov, I., Gross, A., Ronen, Z., Baram, S., Shore, L.S., 2008. Transport of testosterone and estrogen from dairyfarm waste lagoons to groundwater. Environ. Sci. Technol. 42, 5521-5526. https://doi.org/10.1021/es800784m

Barrios, R.E., Gaonkar, O., Snow, D., Li, Y., Li, X., Bartelt-Hunt, S.L., 2019. Enhanced biodegradation of atrazine at high infiltration rates in agricultural soils. Environ. Sci. Process. Impacts 21, 999-1010. https://doi.org/10.1039/c8em00594j

Benotti, M.J., Trenholm, R.A., Vanderford, B.J., Holady, J.C., Stanford, B.D., Snyder, S.A., 2009. Pharmaceuticals and endocrine disrupting compounds in U.S. drinking water. Environ. Sci. Technol. 43, 597-603. https://doi.org/10.1021/ es801845a

Bircher, S., Card, M.L., Zhai, G., Chin, Y.P., Schnoor, J.L., 2015. Sorption, uptake, and biotransformation of $17 \beta$-estradiol, $17 \alpha$-ethinylestradiol, zeranol, and trenbolone acetate by hybrid poplar. Environ. Toxicol. Chem. 34, 2906-2913. https://doi.org/10.1002/etc.3166 
Bloomfield, J.P., Williams, R.J., Gooddy, D.C., Cape, J.N., Guha, P., 2006. Impacts of climate change on the fate and behaviour of pesticides in surface and groundwater - a UK perspective. Sci. Total Environ. 369, 163-177. https://doi. org/10.1016/j.scitotenv.2006.05.019

Caracciolo, A.B., Giuliano, G., Di Corcia, A., Crescenzi, C., Silvestri, C., 2001. Microbial degradation of terbuthylazine in surface soil and subsoil at two different temperatures. Bull. Environ. Contam. Toxicol. 67, 815-820. https://doi. org/10.1007/s001280195

Card, M.L., Schnoor, J.L., Chin, Y.P., 2013. Transformation of natural and synthetic estrogens by maize seedlings. Environ. Sci. Technol. 47, 5101-5108. https://doi. org/10.1021/es3040335

Card, M.L., Schnoor, J.L., Chin, Y.P., 2012. Uptake of natural and synthetic estrogens by maize seedlings. J. Agric. Food Chem. 60, 8264-8271.

Casey, F.X.M., Larsen, G.L., Hakk, H., Šimůnek, J., 2003. Fate and transport of 17 beta-estradiol in soil-water systems. Environ. Sci. Technol. 37, 2400-2409. https://doi.org/10.1021/es026153z

Casey, F.X.M., Simunek, J., Lee, J., Larsen, G.L., Hakk, H., 2005. Sorption, mobility, and transformation of estrogenic hormones in natural soil. J. Environ. Qual. 34, 1372-1379.

Chang, S.W., Lee, S.J., Je, C.H., 2005. Phytoremediation of atrazine by poplar trees: toxicity, uptake, and transformation. J. Environ. Sci. Health Part B Pestic. Food Contam. Agric. Wastes 40, 801-811. https://doi. org/10.1080/03601230500227483

Colucci, M.S., Bork, H., Topp, E., 2001. Persistence of estrogenic hormones in agricultural soils: I . 17ß-estradiol and estrone. J. Environ. Qual. 30, 2070-2076.

Delcour, I., Spanoghe, P., Uyttendaele, M., 2015. Literature review: impact of climate change on pesticide use. Food Res. Int. 68, 7-15. https://doi. org/10.1016/j.foodres.2014.09.030

Dong, X., Sun, H., 2016. Effect of temperature and moisture on degradation of herbicide atrazine in agricultural soil. Int. J. Environ. Agric. Res. 150-157.

Falloon, P., Smith, P., Bradley, R.I., Milne, R., Tomlinson, R., Viner, D., Livermore, M., Brown, T., 2006. RothCUK - a dynamic modelling system for estimating changes in soil $\mathrm{C}$ from mineral soils at $1-\mathrm{km}$ resolution in the UK. Soil Use Manag. 22, 274-288. https://doi.org/10.1111/j.1475-2743.2006.00028.x

Feddes, R.A., Kowalik, P.J., Zaradny, H., 1978. Simulation of Field Water Use and Crop Yield. John Wiley \& Sons, New York, NY.

Gavilán, P., Lorite, I.J., Tornero, S., Berengena, J., 2006. Regional calibration of Hargreaves equation for estimating reference ET in a semiarid environment. Agric. Water Manag. 81, 257-281. https://doi.org/10.1016/j.agwat.2005.05.001 GSI ENVIRONMENTAL INC, 2013. https://www.gsi-net.com/en/

Hallgren, P., Nicolle, A., Hansson, L.-A., Bronmark, C., Nikoleris, L., Hyder, M., Persson, A., 2014. Synthethic estrogen directly affects fish biomass and may indirectly disrupt aquatic food webs. Environ. Toxicol. Chem. 33, 930-936. https://doi.org/10.1002/etc.2528 
Hargreaves, G.H., 1994. Defining and using reference evapotranspiration. J. Irrigat. Drain. Eng. 120, 1132-1139.

Ji, Q., Lee, J., Lin, Y., Jing, G., Tsai, L.J., Chen, A., Hetrick, L., Jocoy, D., Liu, J., 2016. Atrazine and malathion shorten the maturation process of Xenopus laevis oocytes and have an adverse effect on early embryo development. Toxicol. Vitro 32, 63-69. https://doi.org/10.1016/j.tiv.2015.12.006

Kolpin, D.W., Barbash, J.E., Gilliom, R.J., 2002. Atrazine and metolachlor occurrence in shallow ground water of the United States, 1993 to 1995: relations to explanatory factors. J. Am. Water Resour. Assoc. 38, 301-311. https://doi. org/10.1111/j.1752-1688.2002.tb01553.x

Komprda, J., Komprdová, K., Sáňka, M., Možný, M., Nizzetto, L., 2013. Influence of climate and land use change on spatially resolved volatilization of persistent organic pollutants (POPs) from background soils. Environ. Sci. Technol. 47, 7052-7059. https://doi.org/10.1021/es3048784

Kookana, R., Holz, G., Barnes, C., Bubb, K., Fremlin, R., Boardman, B., 2010. Impact of climatic and soil conditions on environmental fate of atrazine used under plantation forestry in Australia. J. Environ. Manag. 91, 2649-2656. https://doi. org/10.1016/j.jenvman.2010.07.037

Lamon, L., Valle, M.D., Critto, A., Marcomini, A., 2009. Introducing an integrated climate change perspective in POPs modelling, monitoring and regulation. Environ. Pollut. 157, 1971-1980. https://doi.org/10.1016/j.envpol.2009.02.016

Lee, L.S., Strock, T.J., Sarmah, A.K., Rao, P.S.C., 2003. Sorption and dissipation of testosterone, estrogens, and their primary transformation products in soils and sediment. Environ. Sci. Technol. 37, 4098-4105. https://doi.org/10.1021/ es020998t

Lin, C.H., Lerch, R.N., Garrett, H.E., George, M.F., 2008. Bioremediation of atrazine-contaminated soil by forage grasses: transformation, uptake, and detoxification. J. Environ. Qual. 37, 196. https://doi.org/10.2134/jeq2006.0503

Ma, J., Cao, Z., 2010. Quantifying the perturbations of persistent organic pollutants induced by climate change. Environ. Sci. Technol. 44, 8567-8573. https://doi.org/10.1021/es101771g

Ma, J., Hung, H., Blanchard, P., 2004. How do climate fluctuations affect persistent organic pollutant distribution in north America? Evidence from a decade of air monitoring. Environ. Sci. Technol. 38, 2538-2543. https://doi.org/10.1021/ es0349610.

McGuire, V.L., Kilpatrick, J.M., 1998. Hydrogeology in the Vicinity of the Nebraska Management Systems Evaluation Area Site, Central Nebraska. U.S. Geological Survey, Water-Resources Investigations Report 97-4266. https://doi. org/10.3133/wri974266

Moeder, M., Carranza-Diaz, O., López-Angulo, G., Vega-Aviña, R., Chávez-Durán, F.A., Jomaa, S., Winkler, U., Schrader, S., Reemtsma, T., Delgado-Vargas, F., 2017. Potential of vegetated ditches to manage organic pollutants derived from agricultural runoff and domestic sewage: a case study in Sinaloa (Mexico). Sci. Total Environ. 598, 1106-1115. https://doi.org/10.1016/j.scitotenv.2017.04.149 
Mualem, Y., 1976. A new model for predicting the hydraulic conductivity of unsaturated porous media. Water Resour. Res. 12, 513-522.

Neuman, S.P., 1990. Universal scaling of hydraulic conductivities and dispersivities in geologic media. Water Resour. Res. 26, 1749-1758.

Qi, Y., Zhang, T.C., 2016. Sorption and desorption of testosterone at environmentally relevant levels: effects of aquatic conditions and soil particle size fractions. J. Environ. Eng. 142, 1-9. https://doi.org/10.1061/(ASCE)EE

Roeth, F.W., Lavy, T.L., 1971. Atrazine uptake by sudangrass, sorghum, and corn. Weed Sci. 19, 93-97.

Rose, E., Paczolt, K.A., Jones, A.G., 2013. The effects of synthetic estrogen exposure on premating and postmating episodes of selection in sex-role-reversed Gulf pipefish. Evol. Appl. 1160-1170. https://doi.org/10.1111/eva.12093

Schepers, J.S., Varvel, G.E., Watts, D.G., 1995. Nitrogen and Water Management Strategies to Reduce Nitrate Leaching under Irrigated Maize 20, pp. 227-239.

Šejna, M., Šimůnek, J., 2007. Hydrus (2D/3D): graphical user interface for the HYDRUS software package simulating two-and three-dimensional movement of water, heat, and multiple solutes in variably-saturated media. Available at: www.pcprogress

Shargil, D., Fine, P., Gerstl, Z., Nitsan, I., Kurtzman, D., 2016. Impact of biosolids and wastewater effluent application to agricultural land on corticosterone content in lettuce plants. Sci. Total Environ. 541, 742-749. https://doi.org/10.1016/j. scitotenv.2015.09.115

Šimůnek, J., Van Genuchten, M.T., Šejna, M., 2012. The HYDRUS Software Package for Simulating the Two- and Three-Dimensional Movement of Water, Heat, and Multiple Solutes in Variably-Saturated Porous Media.

Skamarock, W.C., Klemp, J.B., Dudhia, J., Gill, D.O., Barker, D.M., Duda, M.G., Huang, X.-Y., Wang, W., Powers, J.G., 2008. A Description of the Advanced Research WRF Version 3. NCAR Tech. Note NCAR/TN-475)STR 113 Pp. https://doi. org/10.5065/D68S4MVH Soil and Health Library, 2016.

Sonon, L.S., Schwab, A.P., 2004. Transport and persistence of nitrate, atrazine, and alachlor in large intact soil columns under two levels of moisture content. Soil Sci. 169, 541-553. https://doi.org/10.1097/01.ss.0000138418.14922.0c

Spalding, R.F., Exner, M.E., Snow, D.D., Cassada, D.A., Burbach, M.E., Monson, S.J., 2003a. Herbicides in ground water beneath Nebraska's management systems evaluation area. J. Environ. Qual. 32, 92-99.

Spalding, R.F., Watts, D.G., Schepers, J.S., Burbach, M.E., Exner, M.E., Poreda, R.J., Martin, G.E., 2001. Controlling nitrate leaching in irrigated agriculture. J. Environ. Qual. 30, 1184-1194.

Spalding, R.F., Watts, D.G., Snow, D.D., Cassada, D.A., Exner, M.E., Schepers, J.S., 2003b. Herbicide loading to shallow ground water beneath Nebraska's management systems evaluation area. J. Environ. Qual. 32, 84-91.

Steffens, K., Jarvis, N., Lewan, E., Lindström, B., Kreuger, J., Kjellström, E., Moeys, J., 2015. Direct and indirect effects of climate change on herbicide leaching - a regional scale assessment in Sweden. Sci. Total Environ. 514, 239-249. https:// doi.org/10.1016/j.scitotenv.2014.12.049 
Su, Y.H., Zhu, Y.G., 2006. Bioconcentration of atrazine and chlorophenols into roots and shoots of rice seedlings. Environ. Pollut. 139, 32-39. https://doi. org/10.1016/j.envpol.2005.04.035

Tetreault, G.R., Bennett, C.J., Shires, K., Knight, B., Servos, M.R., McMaster, M.E., 2011. Intersex and reproductive impairment of wild fish exposed to multiple municipal wastewater discharges. Aquat. Toxicol. 104, 278-290. https://doi. org/10.1016/j.aquatox.2011.05.008

University of Nebraska-Lincoln, 2000. Quality-Assessed Agrichemical Contaminant Database for Nebraska Ground Water. http://snr.unl.edu/data/water/ groundwater/groundwaterquality.aspx

Urena-Amate, M.D., Socias-Viciana, M., Gonzalez-Pradas, E., Saifi, M., 2005. Effects of ionic strength and temperature on adsorption of atrazine by a heat treated kerolite. Chemosphere 59, 69-74. https://doi.org/10.1016/j. chemosphere.2004.09.098

Vajda, A.M., Barber, L.B., Gray, J.L., Lopez, E.M., Bolden, A.M., Schoenfuss, H.L., Norris, D.O., 2011. Demasculinization of male fish by wastewater treatment plant effluent. Aquat. Toxicol. 103, 213-221. https://doi.org/10.1016/j. aquatox.2011.02.007

Valle, M.D., Codato, E., Marcomini, A., 2007. Climate change influence on POPs distribution and fate: a case study. Chemosphere 67, 1287-1295. https://doi. org/10.1016/j.chemosphere.2006.12.028

van Genuchten, M.T., 1980. A closed-form equation for predicting the hydraulic conductivity of unsaturated soils. Soil Sci. Soc. Am. J. 44, 892. https://doi. org/10.2136/sssaj1980.03615995004400050002x

Wright, C.K., Wimberly, M.C., 2013. Recent land use change in the Western Corn Belt threatens grasslands and wetlands. Proc. Natl. Acad. Sci. Unit. States Am. 110, 4134-4139. https://doi.org/10.1073/pnas.1215404110 